\title{
Work-life interference and gender in the mining and energy industry
}

\author{
David Peetz, Georgina Murray \& Olav Muurlink
}

Centre for Work, Organisation and Wellbeing

Griffith University, Brisbane

contact: d.peetz@griffith.edu.au

forthcoming as: Peetz, D \& Murray, G \& Muurlink, O, 'Work-life interference, gender and unionism in the mining and energy industry', Labour and Industry. 24(4), 2014, 286-301. DOI: 10.1080/10301763.2014.978968 (Note: check against final published version, which has final corrections, as that is the authoritative one, not this version.) 


\begin{abstract}
In the context of the widespread adoption of 12-hour shifts in the male-dominated mining and energy industry, and using data gathered from 2566 unionised mining and energy workers and 1915 partners, we investigate the extent and gendering of work-life interference in that industry. We ask about the ways, if any, in which work-life interference occurs; whether patterns of interference differ between male and female mineworkers; whether patterns of interference differ between mineworkers and their partners; and how working time preferences affect work-life interference amongst mineworkers and their partners. We find extensive interference, mitigated by predictability and 'blocks of time', but these are not enough to offset the impact of the length and rotation of shifts. Gendering takes several forms. The interaction between the domestic and market spheres leads female mine and energy workers to experience greater interference. Long hours and long shifts create significant work-life interference, and part of the burden is shifted to mineworkers' (mostly female) partners, manifested in shortfalls in full-time labour force participation and in stresses upon the partner.
\end{abstract}




\section{Work-life interference and gender in the mining and energy industry}

Gender has two major dimensions in the mining and energy industry: the distinction between male and female mine and energy workers, and the relations (and distinctions) between (predominantly) male mine and energy workers and their (predominantly) female partners. In the context of the widespread adoption of 12-hour shifts in this historically blue-collar industry, we investigate the ways in which work-life interference differentially or similarly affects male and female mine and energy workers, and their partners. We ask about the ways, if any, in which work-life interference occurs; whether patterns of interference differ between male and female mineworkers; whether patterns of interference differ between mineworkers and their partners; and how working time preferences affect work-life interference amongst mineworkers and their partners. We pay special attention to an aspect of work-life interference, that of exhaustion after work. Our study shows the benefit of focusing on working patterns in a specific industry as employer behaviours reflect the specific circumstances and opportunities within an industry, in the context of a generalised increase in market liberal policy pressures.

\section{Some background literature}

Work life balance refers to the ability to combine paid work with personal activities outside the workplace, including caring responsibilities (Taylor, Robert, 2001). State policy may significantly affect workers' ability to achieve balance and equity (Crompton 
and Lyonette, 2005: 379). While work-life balance or interference and the need for greater flexibility for employees have been the subjects of policy debate over the past two decades, at the same time, the focus on liberal economic policies has potentially made policy interventions more difficult and increased employer power, with pressure for greater flexibility by employees. The intensification of work in Australia and the lengthening of the working week have been noted by many authors (Campbell, 2002; Griffith Work Time Project, 2003; Green, 2004), but eventually resistance grows and increases in work intensity or working hours become unsustainable. Hence the proportion of full-time workers putting in more than 50 hours in a week rose from 19.5 per cent through 1978 to 30.5 per cent through 2000, but gradually eased to 26.5 per cent through 2012 (Australian Bureau of Statistics, 6202.0). The employer response to this generalised resistance may have been to focus attention on getting employees to work whenever suits employers, rather than on getting individual employees to work longer and longer hours each week. For example, employers continue to lobby to reduce or remove penalty rates in the service sector (BCA 2014). The growth of the rotating twelve-hour shift in mining and other areas may be part of such a phenomenon, with employers in mining seeking an increase in maximum shift length.

Work-life interference (where work interferes with the ability to manage personal activities outside the workplace) may be more likely to be an issue in sectors such as mining with high flexibility by employees, for example via long hours and shift work (Mercury: 2013). Adverse effects of long or rotating shifts, noted on issues such as health, fatigue and wellbeing (Folkard and Lombardi, 2006:1; Wang and Chuang, 2014), tiredness (Da Silva, 2006) performance, errors and injury (Nelson, 2012: 19; Wagstaff 
and Lie, 2011:173) all heighten the potential for shift work to create uncertainty, conflict or other interference in home life.

Validakis (2012), writing in a mining trade journal, suggests work life balance is precarious, and miners are 'doing it tough'. Academic research from the South Australian Centre for Work + Life support this, showing mineworkers have 'the worst work-life interference, which is probably a function of both long hours, shift-work and extensive travel requirements (e.g. fly in/fly out arrangements)' (Skinner, Hutchinson and Pocock, 2012). Social and environmental concerns, including about the sustainability and quality of jobs, have led to criticism of media glorification of the 'big miners' - really, the mine owners and the mining companies (Caddick, 2013). The unsustainability of many jobs in the sector is suggested by labour turnover data: labour turnover in mining is amongst the highest of any industry (Australian Bureau of Statistics, 6309.0) and much higher than would be expected given the level of wages in the industry (Peetz and Murray, 2011). Between 1996 and 2010 mining was the only industry, amongst the eight for which continuous data are available, in which labour turnover increased; amongst all industries it was the only one in which turnover increased in the 1996-2006 period (ABS Cat No 6309.0). Some have argued neoliberalism, and the ideology of profit, drives a system 'hell-bent on destruction' in which workers, like the environment, are resources to be 'plundered and exploited' (Hinkson, 2013). 
Some features of mining employment are noteworthy here, starting with long hours. A national average of 51 hours is worked each week by employees in the industry (Australian Bureau of Statistics, 4102.0), nearly 11/2 times the national average. Miners have a wide-ranging array of roster arrangements with typically 12-hour shifts rotating between day and night, though sometimes with other arrangements. Some examples are: 9 days/nights on, 5 days off; and 21 days/nights on, 7 days off. Amongst unionized mines, it is more common for there to be 'even time' or 'symmetric' rosters, where the number of 12-hour days worked is equal to the number of days off, e.g. four days/nights on then four days off. The length and predictability of shifts distinguishes mineworkers from several other occupations.

Some of the literature on difficulties in work-life balance has emphasized the importance of unpaid overtime and the open-ended nature of working hours, especially where employees are paid a salary rather than an hourly wage (Griffith Work Time Project 2003). Thus a lot of the attention has been on white-collar workers, including professionals, para-professionals, managerial and upper sales and administrative workers, who unlike blue-collar workers are not paid by the number of hours they work. The absence of overtime penalties creates an incentive for the employer to increase demands on the employee, the nature of which may be disguised by flexible start and finishing times that may give the illusion of control to employees (e.g. Peetz et al., 2003). Mine production workers, including those in our sample, almost exclusively work for hourly wages, with overtime and shift premiums payable, and so employers cannot get 'free' hours out of employees in the manner typical in the white collar sector. In addition, the rosters are typically highly structured, and for permanent employees 
may be known up to a year in advance in some mines. These limits to employer incentives and the more predictable nature of shift work might mean less interference in personal lives. Whether this predictability offsets the impact of shift length and rotation is an empirical question.

Work-life balance has potentially a strong gender dimension, and that is a focus of this paper. It arises from the natures of both the workplace and of life outside the workplace. There is no shortage of writers arguing that, despite changes in public discourse and attitudes, workplaces remain highly gendered (e.g. Buzzanell, 2001: 517), including in relation to the levels of women's employment, their occupational integration, and the number of hours they work (Pettit and Hook, 2009) and that 'gender inequality in the workplace is in a large part due to bearing and rearing children' particularly when children are young (Pettit in Schwarz, 2010). It is argued that whilst 'women continue to have primary responsibility' for home, family and community connections 'they will not be able to fully realise their potential' in the same way that men can (Loscocco and Bird, 2012: 210). Thus the role of domestic responsibilities is important to investigate in the mining and energy sector.

The experience of women at work is obviously also shaped by the workplace itself including the support they receive there. This may vary according to the gender composition of the workplace. For example, Taylor (2010) found that 'in mixedsex occupations, women report higher levels of workplace support than men; [but] 
in male-dominated occupations, they perceive relatively low levels of support'. If generalizable, this has potentially adverse implications for women working in mining, especially as the communities in which many mineworkers live are themselves increasingly male-dominated as a result of the growth of contractor arrangements associated with 12-hour shifts. For example, in Dysart, in central Queensland, the proportion of people in mining towns on census night who were women fell from 45 per cent in 2001 to only 35 per cent in 2011; falls have also been recorded in other towns such as Middlemount (Qld), Roxby Downs (SA) and Newman (WA) (ABS 2013). Not only supports but also threats may differ by gender. For example, in defining unhealthy work places, 'female employees emphasized emotional abuse and professional discredit' most whilst men 'emphasized abusive working conditions more than women' (Escartin and Rodriguez-Carballeira, 2011:157). Thus we can ask whether women miners, who are in heavily male workplaces, are more likely to be disadvantaged in any ways.

But the gendering of work-life interference is not just about the roles of men and women in the workplace. If the apparent characteristics of one gender are imprinted through its dominant numbers, workplace institutions may emerge that reinforce gender division of labour outside the workplace. For instance, if an occupation is maledominated then this might facilitate shift arrangements that take advantage of that gender imbalance - or at least, companies may create structures that push the burden of adjustment into the household. Hence Rhodes (2005) wrote of how mining companies gained Two for the Price of One - they obtained surplus not only from the on-site labour of the male mineworkers but also from the domestic labour of their wives which 
enabled the male mineworkers to work the long, rotating shifts. Many households are split by 'fly in fly out' arrangements, with the mineworker living on or near the minesite for over half the time while their partner remains in another locality. Thus 41 per cent of people in Middlemount, Qld, on Census night 2011 were 'visitors' - staying overnight for work, but their homes were elsewhere. This proportion was up 10 percentage points (a third) from 2001 (ABS 2013).

While there are many qualitative studies of women in male-dominated occupations (e.g. Kanter, 1977), there are few quantitative comparative studies. Occupations with a high percentage of shift workers are sometimes gendered (Perrucci et al., 2007) and these gender biases (either in favour of males or females) do make the study of the experience of the minority difficult on statistical grounds alone (due to low cell sizes). There are also relatively few large studies that study matched pairs (i.e. the worker and his or her partner) (Muurlink, Peetz and Murray, 2014). So this study represents a rare opportunity to identify the gender differences in these issues. Our research questions are:

o in what ways, if any, does work-life interference occur amongst mining and energy workers;

- do patterns of interference differ between male and female mineworkers?

○ do patterns of interference differ between (predominantly male) mineworkers and their (predominantly female) partners?

○ how do working time preferences affect work-life interference amongst mineworkers and their partners? 
Our data come from one of the world's largest matched worker-partner surveys dealing with shift work. Our study contains several measures not appearing in other studies, and also differs from several others relating to work-life interference by focusing on a blue-collar occupation with long, rotating but mostly predictable shifts.

\section{Method}

The Australian Coal and Energy Survey (ACES), funded through the ARC Linkage Program with the Construction, Forestry, Mining and Energy Union (CFMEU) Mining and Energy Division, has a matched partner design. The instrument comprised a detailed 16-page survey for mining and energy workers and a 12-page survey for their partners. The study uses some key elements of the Standard Shift Work Index (SSI), the Australian Work and life Index (AWALI), instruments from other studies and several designed specifically for this project. Fieldwork was undertaken over four months to December 2011, gathering data from 4500 people, comprising 2566 mining and energy workers who were members of the CFMEU, and 1915 partners, of whom most (1725) were matched to specific members. These represented response rates of $28 \%$ amongst eligible mine and energy workers and, amongst those partners to whom surveys were sent and whose spouses participated, 78\%. Thus we had two, linked survey modules.

The majority (80 per cent) of respondents from the mining and workers module worked in coal mining, with the remainder split between metal mining, power generation and chemical (mostly oil) production. We use the terms 'mine and energy workers' or 'mineworkers' interchangeably to describe them. Participants in the 
partner module who were working were spread across many industries, mostly in the services sector. Just 3 per cent of the mine and energy workers sample were female, and 87 per cent of all mine and energy worker respondents reported being married or living with a partner, a figure that rose to 90 per cent if we included those in a relationship but living alone. Marriage rates were higher amongst male than female workers, the latter having a higher rate of 'de facto' relationships. Males tended to be older and have longer tenure with the industry, employer and workplace than females.

Key questions on hours worked were benchmarked against mining industry data from the AWALI survey. These AWALI data for mining were initially examined by Peetz and Murray, 2011). Where ACES and AWALI asked similar or identical questions, the results closely mirrored each other, a fact that increased confidence in the ACES findings.

To avoid confusion, when referring to couples, we use the term 'spouse' to refer to the mine and energy worker, while 'partner' describes the other member of the couple. In both survey instruments 'partner' was used in questions. 'Spouse' in this paper does not signify marital status, merely that the person referred to is the mine and energy worker (who in turn has a 'partner'). As another convention, we use single asterisks $\left({ }^{*}\right)$ to signify statistical significance at the $5 \%$ level and double asterisks $\left({ }^{* *}\right)$ at the one per cent level. Two tailed tests only are reported. Most data presented here are quantitative in nature. However, we also collected a substantial amount of qualitative data through some open-ended questions. Some illustrative remarks are quoted at times. 


\section{Working hours}

Some 62 per cent of ACES mine and energy workers undertook night shifts. The majority also worked multiple shifts: 60 per cent had two shifts (e.g. day and night); 9 per cent worked three or more; whereas 30 per cent worked only one shift. For just 7 per cent of workers from whom we had data, the average length of shifts was 8 hours or less; for 26 per cent it was $9-11$ hours; for 65 per cent it was 12 hours ( \pm half an hour); and for 2 per cent it was 13 hours or more.

Workers were asked 'including any paid or unpaid overtime, how many hours per week do you work on average in your main job?' They were then immediately asked 'If you could choose the number of hours you work each week, and taking into account how that would affect your income, leisure and domestic activities, how many hours a week would you choose to work?' The median (and modal) employee worked 44 hours per week, and the median full-timer worked 44.5 hours per week. (These numbers are slightly lower than in AWALI, suggesting average hours in unionised (mostly coal) mines are lower than those in non-union (mostly metalliferous) mines.)

The median of preferred hours was 40 per week (as with AWALI), as was the mode. In total, 67 per cent of employees preferred to work less than 44 hours per week. (In AWALI, the figure was 64 per cent.) 
Some 50 per cent of employees in ACES were working more hours than they preferred, even after taking into account how that would affect their income and other activities, while 39 per cent were working the number of hours they preferred and 11 per cent would prefer to be working more hours. These numbers are not significantly different from those in AWALI. Labour market sorting before these data were collected (our respondents were those left after others who were dissatisfied with aspects of working hours had left the industry (Peetz and Murray, 2011)) meant the survey likely understated the gap between employee preferences and hours worked for those who have entered the industry. On the other hand, common method variance might influence some of the results; we circumvent that problem in part through the use of separate data from partners.

\section{Domestic work hours}

Long working hours and long shifts place particular parenting and housework burdens on workers' partners. Table 1 depicts results from three questions about household responsibilities asked of both members and their partners. We show responses from both respondents and, in order to enable member-partner comparisons, also show responses from only those members whose partners completed the partner survey. The table shows female mineworkers were much more likely than male mineworkers to report responsibility for an even share or even a majority of the housework and related responsibilities regarding child rearing. This was the case regardless of whether we examine the perceptions of mineworkers or their partners. Partners consistently reported doing more housework and child rearing than their mineworker spouses reported. 
This gender difference in housework and child rearing provides the context for gendered patterns in work-life interference that we see later.

\section{Work-life interference amongst mine \& energy workers}

We asked mine and energy workers their reasons for working shifts. Some 57 per cent cited 'blocks of leisure time' (i.e. they rated it five or more on a seven-point scale), but only 29 per cent cited 'more convenient for my domestic responsibilities'. (The top response, with 65 per cent, was 'higher rates of pay'.) Nearly half (48 per cent) indicated 'no choice' as one of the reasons. The high frequency of 'blocks of leisure time' as a reason contrasted with low satisfaction with actual free time. We asked, on a 0-10 scale, how satisfied respondents were with their 'amount of free time': 42 per cent scored at the midpoint of satisfaction or below. This question had also been asked in the HILDA survey; there the 2006 average score was 6.67, with slightly higher satisfaction amongst men (6.73) than women (6.62) (Welsh and Berry, 2009). In ACES, satisfaction with free time was lower amongst mining and energy workers (6.21) and especially partners (6.16).

Asked how much work interfered with their ability to maintain or develop connections and friendships in their community, 29 per cent said 'often' or 'almost always', 33 per cent said 'sometimes', while 39 per cent said 'rarely' or 'never'. On whether work prevented them from spending time with family and friends, the result was slightly more negative, with 34 per cent saying this happened 'often' or 'always', while 38 per 
cent said 'sometimes' and 28 per cent 'rarely' or 'never'. Qualitative comments noted the declining frequency of or attendance at 'BBQs, sports, school events' due to 'how late we get home, or our friends are on completely different shifts'.

Figure 1 compares results for several questions, including those two, with similar questions that originally appeared in the AWALI survey. We used four of the five AWALI component questions in ACES, and can compare findings for mining and energy workers with national benchmark data in AWALI taken from 2009. A modified AWALI index comprising those four items had high reliability (indicated by a Crombach's alpha of 0.85 ) but we do not use it below because of important differences between some of the components in the analysis that follows.

\section{---FIGURE 1 ABOUT HERE----}

On three of the four items, ACES respondents appeared to suffer greater work-life interference than the national AWALI sample. Whereas 17 per cent of AWALI respondents said that work interfered 'often' or 'almost always' with their community connections and friendships, this response was given, as mentioned, by 29 per cent of ACES respondents. The proportion who said this happened 'rarely' or 'never' was 20 percentage points lower amongst ACES respondents than within the national AWALI sample. Similarly, ACES respondents were more likely than the national AWALI sample to say that work kept them from spending the time they would like with family or friends, and less likely than the national AWALI sample to say that work rarely or never interfered with their responsibilities or activities outside work. 
On one matter, however, the pattern was reversed: ACES respondents were less likely than the national AWALI sample to report often feeling rushed or pressed for time. This probably reflected the fact that many AWALI respondents who felt this were working unpaid overtime and/or bringing work home with them, which in turn put constant and somewhat unpredictable pressure on their remaining time; whereas for ACES respondents, pre-scheduled paid overtime meant that time use, although constrained, was planned rather than rushed.

We also used several questions that were not part of AWALI. Asked if their work interfered with responsibilities or activities outside work, for 23 per cent of respondents, this happened 'often' or 'almost always'; 37 per cent said 'rarely' or 'never'. Fewer felt that their work hours did not allow them enough time at home (33 per cent) than the opposite (42 per cent). However, most respondents agreed that after work they were too tired to do what they wanted to do at home (64 per cent, compared with 21 per cent disagreeing).

Gender differences in work-life interference

There were gender differences in responses to the AWALI work-life balance questions by mine and energy workers. These are shown in Table 2 . Female mine and energy workers were significantly more likely than males to say that, often or always, work interfered with their community connections. They were also significantly more likely than males to say that work kept them from spending time with family or friends and that they felt rushed for time. These could reflect female employees partners' doing the 
majority of home or care duties. That said, amongst mine and energy workers as a whole, the partner's share of housework was not a good predictor of work-life interference. However, this is likely to reflect reverse causality: mine and energy workers experiencing substantial interference from work to life would have less capacity to undertake housework and therefore more often be in households where their partner did most.

\section{---TABLE 2 ABOUT HERE ---}

On three of these four questions, ACES gender differences were much greater than in the population as a whole as shown through AWALI, and if anything went in the opposite direction. Keep in mind, however, that AWALI gender comparisons are not reported by industry, and thus do not match male and female employees in the same industry, and so the small differences in AWALI on those three questions could reflect the fact that women work in different industries and, overall, for shorter hours than men. The one exception is, again, the question on whether respondents often feel rushed or pressed for time: in ACES female workers still say this more often than male workers, but the difference appeared less pronounced than in AWALI.

Several other questions tapping work-life issues also showed gender differences. These are explored in Table 3. Two questions tapped 'exhaustion from work'. A majority (52 per cent) of female mine and energy workers, but only a minority of males (38 per cent), agreed that when they came home from work they were often so emotionally drained they could not contribute to the family. Women were also, by a large margin, more likely to agree that after work, they were too tired to do things they liked or needed to 
do. By lesser margins, but still significantly, women were more likely to report that long hours were taken for granted at their workplace and their current working hours did not allow them enough time at home. (Women miners had slightly longer average working hours than men, but the difference was only just marginally significant, so this does not really explain the above finding.)

\section{---TABLE 3 ABOUT HERE---}

However, we should not conclude gender differences in exhaustion from work can be attributed solely to domestic workloads. Different workplace experiences appear very important. Table 4 shows ordinary least squares (OLS) regressions predicting excessive tiredness after work (equations 1 and 2), and being emotionally drained after work (equations 3 and 4). In both cases, and consistent with Table 3, gender on its own is a significant predictor of the dependent variable. But when several other variables are added (equations 2 and 4), the size of the coefficient on gender declines by well over half and loses significance. Several important predictors of exhaustion from work emerge. Five correlate with gender. We also created two indices of exhaustion from work, a purer, short version ( $\alpha=.72$, containing just the two variables above), and a longer version $(\alpha=.84)$ that also contained three other variables tapping time congestion (which might be a better way of conceiving the longer index). Appearing as equations 5 and 6, they produced the same pattern: gender significant on its own (not shown for reasons of space), but losing significance when the other variables mentioned below are introduced. 
Job quality affected exhaustion from work. Both measures were higher where respondents agreed their job was repetitive: 71 per cent of female mine and energy workers, compared to 45 per cent of males, agreed. Both exhaustion measures also increased with average shift length, and female employees (being more likely to be in repetitive, production jobs) were more likely to be working shifts of $12+$ hours or night shifts.

Social networks at work also influenced exhaustion. Both measures of exhaustion were higher where respondents disagreed with the statement, 'Where I work, I can depend on people to help if I am in trouble'. Consistent with Taylor's (2010) observation on male-dominated occupations, women workers were more likely to disagree with this statement (27 per cent) than male workers (13 per cent).

Insecurity appeared influential. Both measures were higher when respondents felt more likely to be sacked within the next year. More women (20 per cent) than men (12 per cent) thought there was a 50 per cent or greater chance they would lose their jobs. Physical as well as economic insecurity mattered. Exhaustion measures were higher where respondents felt unsafe as a result of either the attitudes of their fellow employees or company policies. The latter was not related to gender; but women were more likely to say they 'often' felt unsafe as a result of the attitudes of fellow employees (22 per cent) than were men (13 per cent). Exhaustion was also higher amongst workers who wanted to work fewer hours, but this was not related to gender. 


\section{Partners' perspectives on social impact of work patterns}

As mentioned, with time availability predictable but highly restricted, the burden of undertaking household tasks fell to the partner. Amongst female partners who were working, only 38 per cent worked full-time, whereas in the Australian labour force as a whole, 54 per cent of female employees work full-time (Australian Bureau of Statistics, 6202.0). Amongst the female partners of ACES respondents, we saw in Table 2 that over four fifths said they undertook the majority of the housework or, where relevant, dressed children or cared for them when ill.

Several questions tapped partners' perceptions on spousal availability. Asked if their spouse's working hours allow their spouse enough time at home, 25 per cent disagreed, and 57 per cent agreed. Said one partner, 'My [spouse's] shift work is definitely hard for everyone at home, especially having a three year old and newborn'. A larger minority (31 per cent) agreed their spouse's working hours interfered with their ability to maintain connections and friendships in the community, with 48 per cent disagreeing.

Curiously, partners seemed, if anything, slightly less likely to complain about their spouse's tiredness than were the mining and energy workers themselves. While, as mentioned, 64 per cent of mining and energy workers agreed that after work they were too tired to do what they wanted to do at home, only 59 per cent of partners agreed that after work, their spouse comes home too tired to do some of the things they'd like or need them to do; 21 per cent of mining and energy workers, and 27 per cent of partners, disagreed. Some of this problem was in turn internalised by working partners, amongst whom 49 per cent agreed that after work they, themselves, were too tired to do what 
they wanted to do at home (31 per cent disagreed) - even though most were working part-time.

Substantial minorities of partners also expressed other concerns. Some 37 per cent agreed that their spouse was often so emotionally drained when they get home from work that it prevented them from contributing to the family (46 per cent disagreed) but this partner perception of spousal exhaustion was no worse than that reported by the mine and energy workers themselves. Some 31 per cent agreed that their spouse's working hours interfered with the partner's own ability to maintain connections and friendships in the community; and 23 per cent agreed that their spouse's work responsibilities affect the partner's own social life more than they should.

Partners were evenly split on whether they would prefer their spouses to give up working shifts and get a day-time job without shifts. Separately, 20 per cent would like their spouse to get a job elsewhere if it were possible, whereas 58 per cent would not. It is possible that partner disaffection is one part of the explanation for the high labour turnover in the industry, as there is a highly significant correlation $(\mathrm{r}=.19, \mathrm{p}<.001)$ between partner disaffection as registered here and their spouse's reported probability of voluntarily leaving their job within the next year. Where partners strongly agreed that they would rather their spouse got a job elsewhere, only 45 per cent of their spouses thought there was no chance they would quit their job in the next year, but where partners strongly wanted them to stay in the job, some 74 per cent of spouses were certain they would be in the same job in a year's time. 


\section{Working hours preferences and work-life interference}

One reason for mining's poor ranking on work-life interference is the divergence between hours preferred and hours worked (Skinner and Pocock, 2008; Skinner et al 2012). So those ACES respondents who preferred to be working fewer hours scored poorly on AWALI questions: for example, they were twice as likely to say that work 'often' or 'almost always' interferes with activities outside of work. They were also more likely to say work stopped them spending time with their family or friends, and that it interfered with connections and friendships in the community. Overall, while 25 per cent of those working the hours they preferred said they were, often or almost always, rushed and pressed for time, the figure rose to 48 per cent amongst those who wanted to work fewer hours.

The effects were felt not just by mine and energy workers but also by their partners. Amongst partners of mine and energy workers who would prefer to work fewer hours, over half (52 per cent) often or almost always felt rushed or pressed for time, compared to 43 per cent amongst workers whose spouses were content with their hours.

Table 5 shows this and other relationships. Partners of workers who wanted fewer hours were more likely than others to: report exhaustion in their spouses; agree their spouse was often so emotionally drained or came home too tired to do some of the things they should; agree it prevented them from contributing to the family; agree their spouse's working hours interfered with their own ability to maintain connections and friendships in the community; and disagree their spouse seemed relaxed most of the time at home. 
A t-test applied to a scale measuring how happy partners were with their relationship showed that partners of workers with no say over their hours were significantly less happy with their relationship than those whose spouses had some say over their hours.

\section{Conclusions}

While earlier research has shown how open-ended weekly hours ('salaries' rather than 'wages plus overtime pay') can promote interference between work and life, this study shows how time is being reordered for hourly wages workers to create different forms of work-life interference. Working time for our sample was more predictable than for the majority of Australian employees, so they are less rushed for time, as obligations away from work can be arranged in an orderly fashion, even if time is limited. But by other criteria those working in mining and energy had greater work-life interference than occurred in a national sample.

Work-life interference partly reflected employee preferences for working fewer hours wanted by around half of our survivor sample. One reason for mining's poor ranking on work-life interference is the divergence between hours preferred and hours worked. Our data add to refutation of the claim that working hours arrangements in the mining industry are driven primarily by employee preferences. 
Gender has two major dimensions in mining and energy: the differences between male and female mine and energy workers, and the relations (and differences) between (predominantly) male workers and their (predominantly) female partners. Both are influenced by the domestic division of labour. The vast majority of female partners said they undertook the majority of the housework and only one in seven said housework was evenly shared. Female mineworkers were much more likely than male mineworkers to have responsibility for a higher share of household and child-rearing responsibilities.

Within the workplace, women mine and energy workers were more likely than men to report work-life interference, in particular that work affected their community involvement or prevented them spending adequate time with family or friends, and were more likely to feel rushed for time. On most but not all issues, gender differences in our mining and energy sample appeared considerably more adverse for women than in the population as a whole (though the AWALI data did not seek to match employees by industry). Female employees also scored considerably worse than males on two measures of exhaustion from work. These gender differences in exhaustion were likely to be partly attributable to the household division of labour, but also reflected different workplace experiences, such as poorer job quality, more common long shifts, weaker support networks at work for women, and greater feelings of both physical and economic insecurity amongst women workers. 
Looking within the household rather than the workplace, the main way in which the burden of work was transmitted was through generating a shortfall in full-time labour force participation amongst female spouses. However, there were other effects as well. Many negatives reported by mine and energy workers were reported in broadly comparable numbers by their partners, sometimes slightly less so. Partners appeared to internalise some of the problems, so that roughly half of working partners agreed that after work they, themselves, were too tired to do what they wanted to do at home, even though most worked part-time. Partner concerns were heightened where their spouses reported that they wanted to work fewer hours. These partners were most likely to report exhaustion in their spouses and varying degrees of interference in their own lives. Where spouses had no say over their hours, the partners were less happy with their marital relationship.

Our study shows the benefit of focusing on working patterns in a specific industry. While employee resistance had possibly blunted the national trend towards increased working hours and work intensity that was evident from the mid 1980s, employer responses reflected the specific circumstances within particular industries and the opportunities they provided to enable employers to make employees work whenever suited the employer. In the mining and energy sector, where both market and policy pressures have favoured the employer cause, the outcome has been work-life interference and the gendering of it.

Overall, the gendering of work-life interference takes several forms. Interaction between domestic and market spheres means female mine and energy workers experience greater interference than male workers. Long and rotating shifts create 
significant work-life interference, despite rhetoric of family friendliness, and no small part of the burden is shifted from (mostly male) mine and energy workers themselves to their (mostly female) partners. It is manifested partly in shortfalls in full-time labour force participation, and partly in stresses upon the partner. There are different patterns to the population at large but if anything the gendering of work-life interference is stronger here than in the wider community. Mining companies have taken advantage of the greater bargaining power in the context of neo-liberal policy regimes, and a male-dominated workforce, to create shift structures that maximise profit and externalise costs onto employees and their partners and heighten existing gendering patterns.

Of course, this research is not without limitations. Even with the sample size here, the number of women in the employee sample is not as large as would be optimal, an inherent problem in looking at women in male-dominated occupations. Our knowledge of directionality of cause and effect is also constrained by the cross-sectional nature of the survey. The former may be addressed by future researchers operating with larger samples, while we hope to address the latter in part through the next, longitudinal phase of this project.

In the meantime, policy makers would do well to consider the implications of these and other findings regarding work-life interference. Legislative protections for workers against 'unreasonable' hours, that give considerable discretion to magistrates or tribunal members, take as a 'normal' the situation that currently prevails in an industry, so that if it is common for workers to experience work-life interference through the operation of new work arrangements, this new 'normal' cannot be effectively 
challenged (Peetz and Murray, 2011). Policy makers need to consider the ways in which protections against socially unreasonable work arrangements can be improved. 
Figure 1 Work-life interference in ACES 2011 and AWALI 2009

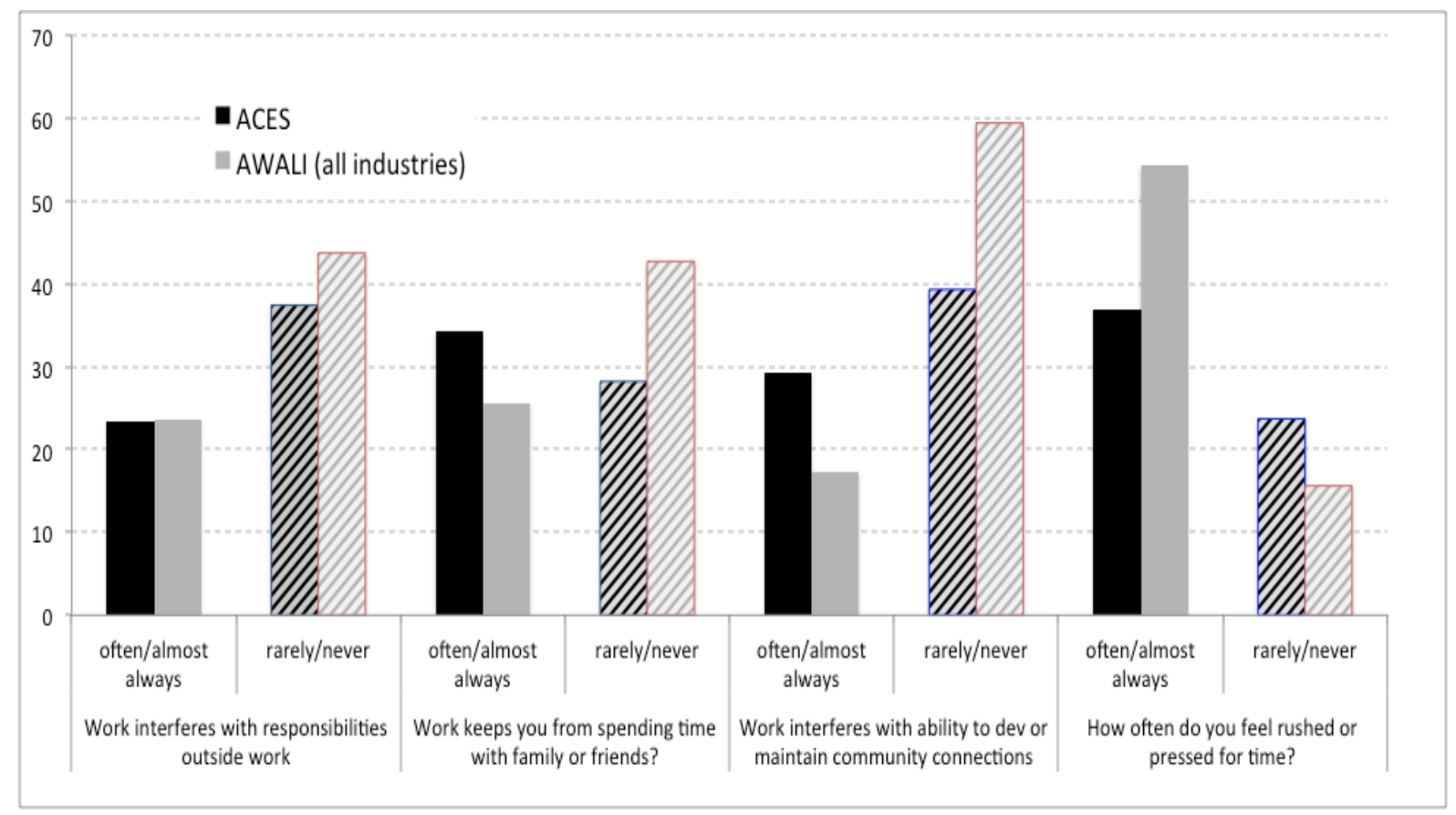

Sources: ACES Wave 1 2011, Mine \& Energy Workers module; AWALI data 2009 as reported in Pocock, Skinner and Ichii, 2009. 


\begin{tabular}{|c|c|c|c|c|c|c|}
\hline & \multicolumn{3}{|c|}{ Female M\&E workers } & \multicolumn{3}{|c|}{ Male M\&E workers } \\
\hline & \multicolumn{2}{|c|}{ M\&E workers responses } & \multirow[t]{2}{*}{$\begin{array}{l}\text { Partner } \\
\text { responses }\end{array}$} & \multicolumn{2}{|c|}{ M\&E workers responses } & \multirow[t]{2}{*}{$\begin{array}{l}\text { Partner } \\
\text { responses }\end{array}$} \\
\hline & $\begin{array}{l}\text { all M\&E } \\
\text { workers }\end{array}$ & $\begin{array}{l}\text { with } \\
\text { partners } \\
\text { completing } \\
\text { survey }\end{array}$ & & $\begin{array}{l}\text { all M\&E } \\
\text { workers }\end{array}$ & $\begin{array}{l}\text { with } \\
\text { partners } \\
\text { completing } \\
\text { survey }\end{array}$ & \\
\hline \multicolumn{7}{|c|}{ How much responsibility do you have for housework? } \\
\hline Partner majority & 5 & 13 & 25 & 50 & 52 & 83 \\
\hline Evenly shared & 21 & 25 & 50 & 33 & 33 & 14 \\
\hline M\&E worker majority & 74 & 63 & 25 & 17 & 14 & 3 \\
\hline Total & 100 & 100 & 100 & 100 & 100 & 100 \\
\hline \multicolumn{7}{|c|}{ Who usually dresses the children in your household? } \\
\hline $\begin{array}{l}\text { Always or Usually M\&E } \\
\text { workers }\end{array}$ & 54 & 33 & 30 & 3 & 1 & 1 \\
\hline $\begin{array}{l}\text { M\&E workers and partner } \\
\text { equally }\end{array}$ & 36 & 42 & 50 & 23 & 22 & 15 \\
\hline $\begin{array}{l}\text { Usually or Always } \\
\text { partner }\end{array}$ & 7 & 17 & 10 & 72 & 75 & 82 \\
\hline $\begin{array}{l}\text { Another person in } \\
\text { household }\end{array}$ & 3 & 8 & 10 & 3 & 2 & 2 \\
\hline Total & 100 & 100 & 100 & 100 & 100 & 100 \\
\hline \multicolumn{7}{|c|}{ Who stays at home with the kids when they are ill? } \\
\hline $\begin{array}{l}\text { Always or Usually M\&E } \\
\text { workers }\end{array}$ & 47 & 25 & 27 & 4 & 1 & 1 \\
\hline $\begin{array}{l}\text { M\&E workers and partner } \\
\text { equally }\end{array}$ & 30 & 33 & 46 & 22 & 22 & 16 \\
\hline $\begin{array}{l}\text { Usually or Always } \\
\text { partner }\end{array}$ & 17 & 33 & 18 & 75 & 75 & 81 \\
\hline $\begin{array}{l}\text { Another person in } \\
\text { household }\end{array}$ & 7 & 8 & 9 & 2 & 2 & 1 \\
\hline Total & 100 & 100 & 100 & 100 & 100 & 100 \\
\hline
\end{tabular}

Sources: ACES Wave 1 2011, Mine \& Energy Workers module (data columns 1,2,4 \& 5), partners module (data columns 3 \& 6). Excludes refusals and nil responses. Questions regarding children only asked of parents. 
Table 2: Responses to work-life balance questions by gender, ACES and AWALI.

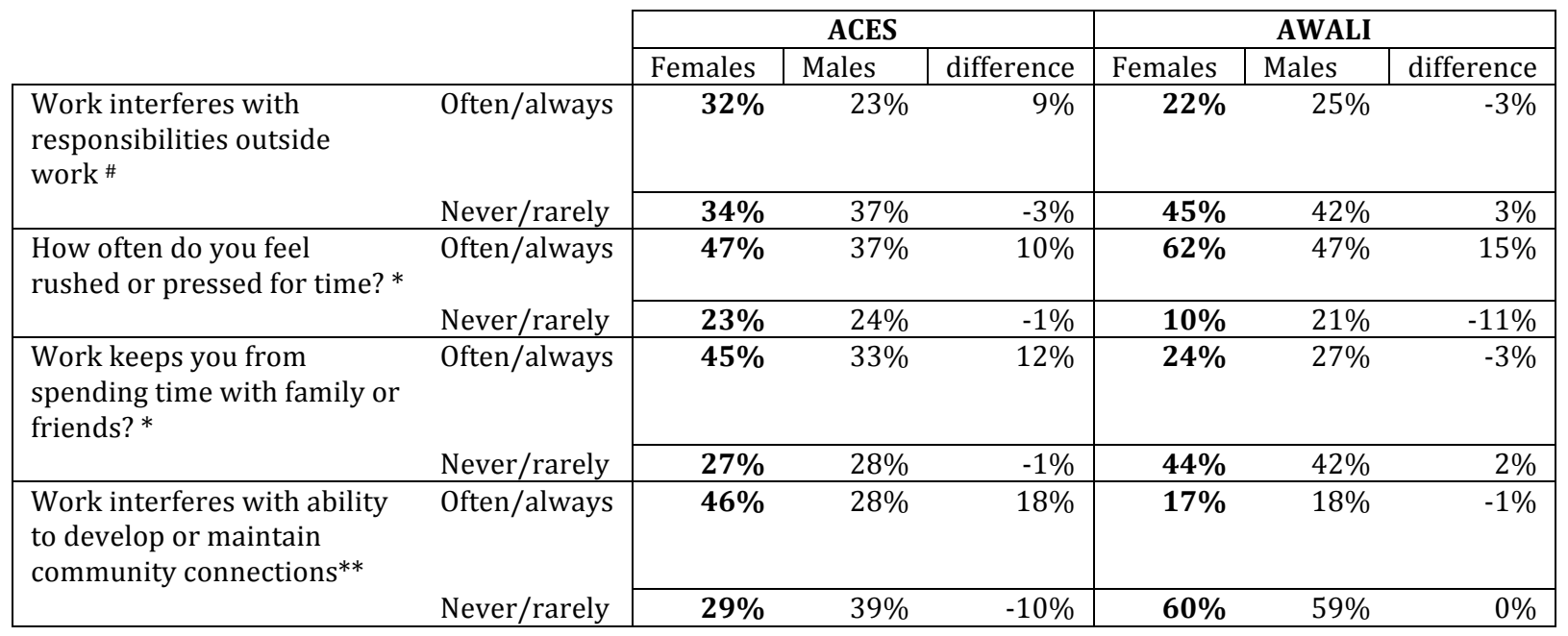

Sources: ACES Wave 1 2011, Mine \& Energy Workers module; AWALI data 2009 as reported in Pocock, Skinner and Ichii, 2009. 
Table 3: Responses to work-life questions, ACES, means and agreement by gender

\begin{tabular}{|l|c|c|c|c|c|c|c|c|}
\cline { 2 - 9 } \multicolumn{1}{c|}{} & \multicolumn{3}{c|}{ Mean score (1=disagree, 7=agree) } & \multicolumn{3}{c|}{$\%$ Agreement } \\
\cline { 2 - 9 } \multicolumn{1}{c|}{} & Female & Male & Difference & t-score & t-sig & Female & Male & Difference \\
\hline $\begin{array}{l}\text { After work, too tired to } \\
\text { need to do }\end{array}$ & 5.59 & 4.95 & $0.63^{* *}$ & 3.99 & .000 & $79.4 \%$ & $63.7 \%$ & $15.6 \%$ \\
\hline $\begin{array}{l}\text { Often so emotionally } \\
\text { drained can't contribute } \\
\text { to family }\end{array}$ & 4.30 & 3.80 & $0.50^{* *}$ & 2.63 & .009 & $52.1 \%$ & $38.0 \%$ & $14.0 \%$ \\
\hline $\begin{array}{l}\text { Long hours are taken for } \\
\text { granted at workplace }\end{array}$ & 5.55 & 4.93 & $0.62^{* *}$ & 3.23 & .001 & $73.5 \%$ & $62.2 \%$ & $11.3 \%$ \\
\hline $\begin{array}{l}\text { My current working } \\
\text { hours do not allow me } \\
\text { enough time at home }\end{array}$ & 4.22 & 3.81 & $0.41^{*}$ & 2.08 & .037 & $42.3 \%$ & $32.7 \%$ & $9.6 \%$ \\
\hline
\end{tabular}

Source: ACES Wave 1 2011, Mine \& Energy Workers module. 
Table 4 OLS predictors of exhaustion from work

\begin{tabular}{|c|c|c|c|c|c|c|}
\hline & \multicolumn{2}{|c|}{$\begin{array}{c}\text { After work, too tired to } \\
\text { do some things I like or } \\
\text { need to do }\end{array}$} & \multicolumn{2}{|c|}{$\begin{array}{l}\text { Often so emotionally } \\
\text { drained can't } \\
\text { contribute to family }\end{array}$} & \multirow{2}{*}{$\begin{array}{c}\text { Short } \\
\text { exhaustion } \\
\text { index (a) }\end{array}$} & \multirow{2}{*}{$\begin{array}{c}\text { Long } \\
\text { exhaustion } \\
\text { index (b) }\end{array}$} \\
\hline & (1) & $(2)$ & (3) & $(4)$ & & \\
\hline \multirow[t]{2}{*}{ (Constant) } & $6.223^{`}$ & 2.445 & 4.803 & 0.733 & 3.199 & 9.504 \\
\hline & $(17.34)$ & $(4.537)$ & $(12.78)$ & $(1.343)$ & (3.408) & (4.495) \\
\hline \multirow[t]{2}{*}{ GENDER } & -0.635 & -0.291 & -0.501 & -0.200 & -.489 & -.779 \\
\hline & $(-3.48)$ & $(-1.50)$ & $(-2.62)$ & $(-1.02)$ & $(-1.453)$ & $(-1.028)$ \\
\hline \multirow[t]{2}{*}{ My job is repetitive } & & 0.117 & & 0.077 & .191 & .407 \\
\hline & & $(5.932)$ & & $(3.885)$ & $(5.555)$ & $(5.252)$ \\
\hline \multirow[t]{2}{*}{$\begin{array}{l}\text { Where I work, I can depend on } \\
\text { people to help if I am in trouble }\end{array}$} & & -0.058 & & -0.099 & -.164 & -.401 \\
\hline & & $(-2.267)$ & & $(-3.794)$ & $(-3.663)$ & $(-3.943)$ \\
\hline \multirow[t]{2}{*}{$\begin{array}{l}\text { Feel unsafe, due to attitudes of } \\
\text { fellow workers }\end{array}$} & & 0.180 & & 0.346 & .535 & .823 \\
\hline & & $(2.735)$ & & $(5.175)$ & (4.639) & (3.164) \\
\hline \multirow[t]{2}{*}{ Perceived chance of being sacked } & & 0.081 & & 0.077 & .159 & .302 \\
\hline & & $(4.514)$ & & $(4.243)$ & $(5.065)$ & $(4.252)$ \\
\hline \multirow[t]{2}{*}{ Average shift length (unweighted) } & & 0.132 & & 0.145 & .278 & .432 \\
\hline & & $(5.174)$ & & $(5.633)$ & $(6.248)$ & $(4.296)$ \\
\hline \multirow[t]{2}{*}{ Prefer to work fewer hours } & & .648 & & .662 & 1.301 & 3.674 \\
\hline & & $(8.352)$ & & $(8.431)$ & $(9.604)$ & $(11.998)$ \\
\hline \multirow[t]{2}{*}{ Feel unsafe, due to company policies } & & .357 & & .518 & .880 & 2.336 \\
\hline & & $(5.639)$ & & $(8.095)$ & (7.961) & $(9.346)$ \\
\hline $\mathrm{N}$ & 2529 & 1845 & 2576 & 1839 & 1826 & 1808 \\
\hline Adjusted R Square & .004 & .146 & .002 & .191 & .214 & .229 \\
\hline $\mathrm{F}$ & 12.166 & 40.547 & 6.916 & 55.265 & 63.131 & 67.943 \\
\hline Sig. & .000 & .000 & .009 & .000 & .000 & .000 \\
\hline
\end{tabular}

Source: ACES Wave 1 2011, Mine \& Energy Workers module.

(a) Comprises the two items in data columns 1-4.

(b) Comprises the short index plus The time I work means I can't fully participate in household activities, My current working hours do not allow me enough time at home, and My current working hours are a source of complaint. 
Table 5 Relationship between preferences-hours worked discrepancy amongst mining and energy workers and their partners' views on various issues

\begin{tabular}{|c|c|c|}
\hline Partner views: & $\begin{array}{c}\text { agreement amongst partners } \\
\text { whose spouse preferred to work } \\
\text { fewer hours }\end{array}$ & $\begin{array}{l}\text { agreement amongst partners } \\
\text { whose spouse preferred to work } \\
\text { same number of hours }\end{array}$ \\
\hline $\begin{array}{l}\text { Often or almost always feel rushed } \\
\text { or pressed for time* }\end{array}$ & 52 & 43 \\
\hline $\begin{array}{l}\text { My spouse is often so emotionally } \\
\text { drained when they get home from } \\
\text { work that it prevents them from } \\
\text { contributing to the family* }\end{array}$ & 44 & 28 \\
\hline $\begin{array}{l}\text { After work, my spouse comes } \\
\text { home too tired to do some of the } \\
\text { things l'd like them or need them } \\
\text { to do* }\end{array}$ & 64 & 52 \\
\hline $\begin{array}{l}\text { My spouse's working hours } \\
\text { interferes with my ability to } \\
\text { maintain connections and } \\
\text { friendships in the community* }\end{array}$ & 36 & 25 \\
\hline $\begin{array}{l}\text { Disagree that: my spouse seems } \\
\text { relaxed most of the time at home* }\end{array}$ & 40 & 25 \\
\hline $\begin{array}{l}\text { Spouse working night shifts make } \\
\text { you anxious - often* }\end{array}$ & 28 & 19 \\
\hline $\begin{array}{l}\text { Would prefer your spouse gave up } \\
\text { working shifts and got day time } \\
\text { job* }\end{array}$ & 50 & 32 \\
\hline
\end{tabular}

Source: ACES Wave 12011 , partners module.

$N=780$ (prefer fewer hours), 596 (prefer same hours).

Note: The term 'partner' used in the questionnaire has been replaced by 'spouse' in this table, to maintain consistency with our naming convention. 


\section{References}

Australian Bureau of Statistics (4102.0) Australian Social Trends. Canberra: April 2013. Australian Bureau of Statistics (6202.0) Labour Force, Australia. Canberra.

Australian Bureau of Statistics (6309.0) Labour Mobility, Australia. Canberra: various years.

Buzzanell, P M (2001) 'Gendered practices in the contemporary workplace' Management Communication Quarterly: McQ 14 (3) pp. 517-537.

Caddick, A (2013) 'Mining earth' Arena Magazine, 124 (online) pp. 2-3.

Campbell, I (2002) 'Extended working hours in Australia' Labour and Industry, 13 (1) pp. 91-110.

Crompton, R \& Lyonette, C (2005) 'The new gender essentialism - domestic and family 'choices' and their relation to attitudes' British Journal of Sociology, 56 (4) pp. 601-620.

Escartin, J, Salin, D. \& Rodriguez-Carballeira, Á (2011) 'Conceptualizations of Workplace Bullying: Gendered Rather Than Gender Neutral?' Journal of Personnel Psychology, 10 (4) pp. 157-165.

Folkard, S \& Lombardi, D (2006) 'Modeling the impact of the components of long work hours on injuries and "accidents"' Americal Journal of Industrial Medicine, 49 (11) pp. 953-963.

Green, F (2004) 'Why Has Work Effort Become More Intense?' Industrial Relations: A Journal of Economy and Society, 43 (4) pp. 709-741.

Griffith Work Time Project (2003) Working time Transformations and Effects, Queensland Department of Industrial Relations, Brisbane.

Hinkson, J (2013) 'The mining equation' Arena Magazine, 124 (online) pp. 5-7.

Kanter, R M (1977) 'Some Effects of Proportions on Group Life: Skewed Sex Ratios and Responses to Token Women' American Journal of Sociology, 82 (5).

Loscocco, K \& Bird, S (2012) 'Gendered paths: Why women lag behind men in small business success' Work and Occupations, 39 pp. 183-219.

Muurlink, O, Peetz, D \& Murray, G (2014) 'Work-related influences on marital satisfaction amongst shiftworkers and their partners: a large, matched-pairs study' Community, Work \& Family, forthcoming.

Nelson, R (2012) 'Long work hours for nurses' American Journal of Nursing, 112 (5) pp. 19-20.

Peetz, D \& Murray, G (2011) "You Get Really Old, Really Quick': Involuntary Long Hours in the Mining Industry' Journal of Industrial Relations, 53 (1) pp. 13-29.

Peetz, D, Townsend, K, Russell, R, Houghton, C, Fox, A \& Allan, C (2003) 'Race Against Time: Extended Hours in Australia' Australian Bulletin of Labour, 29 (2) pp. 126142.

Perrucci, R, MacDermid, S, et al. (2007) 'The significance of shift work: Current status and future directions' Journal of Family and Economic Issues, 28 (4) pp. 600-617.

Pettit, B \& Hook, J L (2009) Gendered tradeoffs: Family, social policy, and economic inequality in twenty-one countries., Russell Sage Foundation, New York.

Pocock, B, Skinner, N \& Ichii, R (2009) Work, Life \& Workplace Flexibility: The Australian Work and Life Index 2009, Centre for Work + Life, University of South Australia, Adelaide.

Rhodes, L (2005) Two for the price of one, the lives of mining wives, API Network, Perth.

Schwarz, J. (2010) "Workplace gendered tradeoffs lead to economic inequalities for women." Seattle, University of Washington. from 
http://www.washington.edu/news/2010/02/25/workplace-genderedtradeoffs-lead-to-economic-inequalities-for-women/.

Skinner, N, Hutchinson, C \& Pocock, B (2012) The big squeeze: Australian Work and Life Index 2012, Centre for Work + Life, University of South Australia, Adelaide. <http://w3.unisa.edu.au/hawkeinstitute/cwl/documents/AWALI2012National.pdf\%3E.

Skinner, N \& Pocock, B (2008) Work, Life \& Workplace Culture: The Australian Work and Life Index 2008, Centre for Work + Life, University of South Australia, Adelaide.

Taylor, C J (2010) 'Occupational Sex Composition and the Gendered Availability of Workplace Support' Gender \& Society, 24 (2) pp. 189-212.

Taylor, R (2001) The Future of Work Life Balance, Economic and Social Research Council, Swindon, UK.

Validakis, V (2012) 'Mining jobs blamed for poor work-life balance ' Australian Mining.

Wagstaff, A \& Lie, J (2011) 'Shift and night work and long working hours - a systematic review of safety implications' Scandinavian Journal of Work Environment and Health, 37 (3) pp. 173-185.

Wang, T-C \& Chuang, L-H (2014) 'Psychological and physiological fatigue variation and fatigue factors in aircraft line maintenance crews' International Journal of Industrial Ergonomics, 44 (1) pp. 107-113.

Welsh, J A \& Berry, H L (2009) 'Social capital and mental health and well-being'. Biennial HILDA Survey Research Conference, Melbourne. 